\title{
Emekli Bireylerin Bir Serbest Zaman Etkinliği Olarak Fiziksel Aktivitelere Dair Görüşleri: Türkiye'nin En Yaşlı ve Mutlu İli Sinop Örneği ${ }^{1}$
}

\author{
$* * *$

\section{Opinions of Retired People about Physical Activity as a Leisure Time Activity: Example of Turkey's Oldest and Happy City ${ }^{1}$}

\author{
Araş. Gör. Nedim Tekin \\ Sinop Üniversitesi, Spor Bilimleri Fakültesi, ntekin@sinop.edu.tr \\ ORCID: 0000-0002-6249-3862 \\ Öğr. Gör. Fatih Mehmet Parlar \\ Artvin Çoruh Üniversitesi, Arhavi Meslek Yüksekokulu, fatihmehmetparlar@artvin.edu.tr \\ ORCID: 0000-0002-3401-4078 \\ Dr. Öğr. Üyesi Özge Ercan \\ Sinop Üniversitesi, Spor Bilimleri Fakültesi, oercan@ sinop.edu.tr \\ ORCID: 0000-0002-627-8347
}

\begin{abstract}
Özet
Bu araştırmada, TÜİK 2019 verilerine göre Türkiye'de mutluluk düzeyi en yüksek il olarak belirlenen Sinop'taki emekli bireylerin; serbest zamanlarını değerlendirme, fiziksel aktiviteye katılım, fiziksel aktivitelerin yeterliği ve katılıma engel durumlar ile şehirde serbest zamanla ilgili değiştirilmesi gerekenlerle ilgili görüşlerini tespit etmek amaçlanmıştır. Çalışma verileri, nitel araştırma desenlerinden yüz yüze görüşme tekniği ile toplanmış ve Sinop şehir merkezinde yaşayan emekli sekiz kişinin görüşleri alınarak içerik analizi tekniği ile çözümlenmiştir. Çalışma neticesinde katılımcı görüşleri; serbest zamanlarını değerlendirme boyutunda fiziksel aktivite, sosyal etkinlikler, açık hava etkinlikleri, mental aktiviteler ve sosyal sorumluluk alanlarında olduğu; fiziksel aktiviteye katılımın sağlık, yenilenme, teşvik ve tatmin boyutlarına ayrıştı̆̆ı; fiziksel aktivitelerin uzman eksikliği, yerel yönetim ve fiziki imkanlar açısından yetersiz olduğu, fiziksel aktivitelere katılıma engel durumların tesis/malzeme, ulaşım, sosyal çevre, beslenme ve bürokrasi boyutlarında gerçekleştiği ve son olarak şehirde serbest zamanla ilgili yapılması/değiştirilmesi gerekenlere dair görüşlerin tesis, kurslar, ulaşım, aktivite, sağlık ve sporu yaygınlaştırma boyutlarında olduğu tespit edilmiştir.
\end{abstract}

Anahtar Kelimeler: Fiziksel aktivite, serbest zaman, emekli bireyler, Sinop

JEL Sınıflandırması: L83

\begin{abstract}
In this research, it is aimed to determine the views of pensioners in Sinop, which is determined to be the province in Turkey with the highest happiness level according to TUIK 2019 data; on the issues that need to be changed relating with evaluating free time, participation in physical activity, adequacy of physical activities, obstacles to participation and free time in the city. The study data were collected from the qualitative research patterns by face-to-face interview technique and the opinions of eight retired people living in the city center of Sinop were obtained and analyzed by content analysis technique. As a result of the research, the following opinions of the participants have been determined: In the dimension of physical activity, social activities, outdoor activities, mental activities and social responsibility;
\end{abstract}

\footnotetext{
${ }^{1}$ Bu araştırma, 17. Uluslararası Spor Bilimleri Kongresi’nde Sözlü Bildiri olarak sunulmuş ve kongre kitapçı̆̆ında özet bildiri olarak yayımlanmıştır.

${ }^{1}$ This research was presented as a Oral Presentation at the 17th International Congress of Sports Sciences and published as a summary in the congress booklet.
} 
in the dimension of participation in physical activity, health, renewal, encouragement and satisfaction, insufficiency of physical activities in terms of lack of experts, local government and physical facilities; in the dimension of situations where obstacles to participation in physical activities take place in the availability of facility/material, transportation, social environment, nutrition and bureaucracy are recognised. And finally it has been determined that opinions about the things to be done/changed about free time in the city are in the dimensions related with facilities, courses, transportation, activity, health and sports.

Keywords: Physical activity, leisure time, retired people, Sinop

JEL Classification: L83

\section{GİRIŞ}

Bilim ve teknoloji alanında yaşanan gelişmeler topluma çeşitli faydalar sağladığı gibi çalışan insanların günlük çalışma saatlerinde de olumlu anlamda değişimlere yol açmıştır (Mahiroğulları, 2005). Öyle ki, Endüstri Devriminin başlarında 14-16 saatlere kadar çıkan çalışma saatleri (Brizon, 1977: 450) bu gelişmelerden dolayı kısalmaya başlamıştır. Bununla beraber yönetim bilimi alanındaki yenilikler, örgütlerin insan faktöründen yararlanma durumunu etkilemiş, çalışma sürelerinin kısalmasını ve çalışanların izin ve tatil sürelerinin artmasını sağlamıştır (Keser, 2009). Çalışanlar lehine yaşanan bu değişimler serbest zaman kavramının ortaya çıkmasına ortam hazırlamıştır (Gorz, 2001:12).

Serbest zaman bireylerin, içinde yaşadıkları sosyal düzen içinde yaşamlarını sürdürmek ve yüksek bir düzeye ulaşabilmede, zaruri olarak yaptığ fillerin dışında, kendi isteklerine göre özgür olarak tükettikleri süredir (Mansuroğlu, 2002). Bireyler serbest olarak değerlendirebildikleri zamanlarda günlük stresten kaçmak için kendini yenileme gereksinimi hissetmekte ve bunu gidermede farklı etkinliklere yönelme davranışları sergilemektedir (Hazar, 2003: 29). Bireylerin bu amaçla serbest zamanlarında bireyler ya da grup olarak yaptıkları etkinliklere genel olarak rekreatif etkinlikler denilmektedir.

Rekreasyon, yenilenme, yeniden şekillenme manasına gelen Latin dilinde "Recreatio" kelimesinden ortaya çıkmış ve Türkçe' de ise rutin iş ve/veya iş hayatında tekrar enerji elde etmede genellikle iş dışı zaman diliminde, pozitif/olumlu faaliyetleri barındıran ve sosyal hayatta kabul görebilen serbest zaman etkinliği olarak tarif edilmektedir (Özbey \& Çelebi, 2014). Genel olarak serbest zamanlarda yeniden tazelenme, iş stresinden uzaklaşma ve kişisel doyuma ulaşma amacıyla yapılmakta olan rekreasyon; günümüzde oldukça geniş kitlelere ulaşmış bir terimdir ve endüstriyel toplumun gelişimi ile arasında yakın bir ilişki vardır (Torkildsen, 1992: 64).

Rekreatif amaçlı etkinlikler çeşitli türlerde olabilmektedir. Fiziksel aktivite/spor içerikli etkinlikler, sanatsal etkinlikler veya sosyalleşmeye dayalı etkinlikler örnek olarak gösterilebilir (Aksoy, Barış \& Ünveren, 2018). Burada önemli olan kişinin serbest zaman içerisinde dinlenebilmesi ve yenilenebilmesidir (Önder, 2003). Rekreasyon aktivitelerinin içerisinde en geniş yeri fiziksel ve sportif etkinlikler almaktadır (Uzun \& Gözaydın, 2017). Fiziksel ve sportif etkinlikler, cinsiyet ayrımı yapılmadan her yaştan insanın ve grubun ilgi ve istekleri doğrultusunda gerçekleştirilir.

Günümüz sosyal sistemi dikkate alındığında en fazla serbest zamana sahip gruplardan birinin emekli bireyler olduğu bilinmektedir. Özellikle bu yaş grubu, Türkiye nüfusunun dikkate değer bir bölümünü (7 milyon 186 bin 204 kişi) oluşturmaktadır (TÜİK, 2019). Türkiye'de bireylerin emeklilik sonrası hayatlarını araştıran birçok bilimsel çalışma yapılmıştır. Şimşek ve Büyükkıdık (2015) yaptıkları çalışmada emekli erkek ögretmenlerin serbest zamanlarını genellikle kahvehanelerde kullandıkları; televizyon izleyip dernek faaliyetlerinde yer aldıklarını, çeşitli yayınları takip ettiklerini, kurs ve aktivitelere dahil olduklarını, tarım ve hayvancılık işiyle ilgilendikleri sonucuna ulaşmışlardır. Sevim ve Şahin (2007) ise çalışmalarında emeklilerin yarısından çoğunun emeklilik dönemine ilişkin bir plan yapmaksızın emeklilik dönemine hazırlıksız girdiklerini tespit etmiştir. Emeklilik dönemine dair planları olduğunu ifade eden sınırlı sayıdaki 
öğretmense çoğunlukla ailesine ve kendisine süre ayırmayı, farklı bir işe atılmayı, çeşitli sosyal projelerde yer almayı düşündüklerini belirtmiştir.

Yaşlılık dönemi ile alakalı yapılan pek çok araştırmada, rekreatif bir aktivite olarak sporu tercih eden yaşlı fertlerin bundan sağlıklarının pozitif yönlü etkilendiği ve yaşam standartlarının arttı̆̆ tespit edilmiştir. Başka bir ifade ile sporun, insanların tekrardan sosyalleşmesine ve özellikle emekli olan yaşlıların sosyal sorunlarının çözümüne katkı verdiği bilinmektedir (Lee vd., 2014). Dolayısıyla emeklilik dönemindeki bireylerin serbest zamanlarında fiziksel aktivite ve sporun önemli bir etkinlik olmasının yanında sağlıklı bir yaşam sürdürmeleri için bir gereklilik olduğu anlaşılmaktadır.

Türkiye'deki yedi coğrafi bölgede bulunan toplam 81 ilin kendine has sosyolojik özellikleri olup bu bölge ve iller demografi ve gelişmişlik düzeyi açısından farklı1ıklar göstermektedir. 81 İl arasından Sinop ili bazı özellikleri bakımından diğer illere göre farklılıklar arz etmektedir. Karadeniz Bölgesi'nin Orta Karadeniz Bölümü'nde bulunan Sinop, Türkiye'nin en yaşlı nüfusa $(18,8)$ sahip ili (TÜİK, 2020) olarak kayıtlara geçerken aynı zamanda da en mutlu ili $(\% 77,66)$ olarak sık sık gündeme gelmektedir (TÜíK, 2020). Gelişmişlik düzeyi bakımından kendisine 52. sırada yer bulan Sinop'un bu özellikleri bilhassa emekli bireylerin serbest zamanlarını nasıl değerlendirdikleri sorusunu akıllara getirmektedir (SEGE, 2017: 56). Zira fiziksel aktivite ve sporun sağlık açısından bireylere sağladığı faydaların yanında zihinsel olarak rahatlamalarına ve eğlence ihtiyaçlarının karşılanmasında etkili olduğu bilim insanları tarafından vurgulanmaktadir.

Dolayısıyla bu çalışma, en yüksek yaş ortalamasına sahip ve gelişmişlik düzeyi bakımından 81 il arasında 52. sırada olmasına rağmen Türkiye'nin en mutlu illeri listesinde ilk sırada bulunan Sinop'taki emekli bireylerin; serbest zamanlarını değerlendirme, fiziksel aktiviteye katılım, fiziksel aktivitelerin yeterliği ve fiziksel aktivitelere katılımlarına engel durumlar ile şehirde serbest zamanla ilgili değiştirilmesi/yenilenmesi gerekenlerle ilgili görüşlerini tespit etmek amacıyla yapılmış ve aşağıda yer alan sorulara cevap bulunması hedeflenmiştir.

\section{Emekli bireylerin serbest zamanlarını hangi aktivitelerle değerlendirdiklerine dair görüşleri nedir?}

2. Emekli bireylerin serbest zamanlarda fiziksel aktivite/spor etkinliklerine katılıma dair görüşleri nedir?

3. Emekli bireylerin Sinop ilinde serbest zamanlarda yapılabilecek fiziksel aktivite/sportif etkinliklerin yeterliğine dair görüsleri nedir?

4. Emekli bireylerin Sinop ilinde geçirdikleri serbest zamanlarda fiziksel aktivitelere/sportif etkinliklere katılıma engel olan durumlar hakkındaki görüşleri nedir?

5. Emekli bireylerin Sinop ilinde serbest zaman etkinlikleri adına nelerin değiştirilmesi/yenilenmesi gerektiğine dair görüşleri nedir?

\section{YÖNTEM}

Bu çalışmada, algı ve olguların tabii ortamında gerçek ve bütün olarak meydana getirmeye imkân tanıyan (Creswell, 2013; Yıldırım ve Şimşek, 2008) nitel araştırma yönteminden faydalanılmıştır. Çalışma deseni olarak nitel araştırmalarda sıkça kullanılan farkında olunan fakat derin bir şekilde ve detaylıca bir bilgiye sahip olunmayan olgulara odaklanan olgu-bilim (Yıldırım ve Şimşek, 2008) kullanılmıştır.

\subsection{Araştırma Grubu}

Çalışmada, amaçlı örneklem yönteminden ölçüt örneklem tekniğinden yararlanılmıştır. Bu teknikteki temel olan belirli kriterleri sağlayan bütün hallerin değerlendirilmesidir (Yıldırım ve Şimşek, 2008). Bu bağlamda araştırma katılımcılarının Sinop ilinde yaşaması ve emekli olmasıdır. 
Tablo 1. Katılımc1 profili

\begin{tabular}{ccccccc}
\hline No & Yaş & Cinsiyet & $\begin{array}{c}\text { Eğitim } \\
\text { Durumu }\end{array}$ & Meslek & $\begin{array}{c}\text { Günlük Ort. } \\
\text { Serbest } \\
\text { Zaman }\end{array}$ & $\begin{array}{c}\text { İde } \\
\text { Bulunduğu } \\
\text { Süre }\end{array}$ \\
\hline G1 & 63 & E & Lisans & Emekli eğitim yöneticisi & 6 saat & 5 y1l \\
\hline G2 & 64 & E & Lisans & Emekli mahalli idareler müdürü & 7 saat & 29 y1l \\
\hline G3 & 73 & E & Lisans & Emekli tapu kadastro müdürü & 14 saat & 40 y1l \\
\hline G4 & 54 & E & Lisans & Emekli banka müdür yardımcis1 & 5 saat & 40 y1l \\
\hline G5 & 53 & K & Lisans & Emekli memur & 8 saat & 53 y1l \\
\hline G6 & 52 & K & Orta Öğretim & Emekli memur & $4-5$ saat & 52 y1l \\
\hline G7 & 52 & K & Lisans & Emekli memur & 4 saat & 10 y1l \\
\hline G8 & 70 & E & Lisans & Emekli şube müdürü & 14 saat & 1 y1l \\
\hline
\end{tabular}

\subsection{Geçerlik ve Güvenirlik}

Çalışma verilerinin geçerlik ve güvenirliği için nitel araştırmalarda kullanılan "İnandırıcılık", "Aktarılabilirlik", "Tutarlık" ve "Teyit edilebilirlik" tekniklerinden yararlanılmıştır (Creswell, 2013; Yıldırım ve Şimşek, 2006). Araştırmada verilerin inandırıcılı̆̆g konusunda "Uzun süre etkileşim”, "uzman incelemesi" ve "katılımcı teyidi" taktikleri kullanılmıştır. Verilerin aktarılabilir olmasını sağlamada ise "amaçlı örneklem" seçimi tercih edilmiştir. Tutarlık için Miles ve Huberman'ın (1994) "Görüş Birliği / (Görüş Birliği+Görüş Ayrılığı)” tekniği kullanılmış ve \%87 uyum skoru bulunmuştur. Teyit edilebilirlik içinse çalışmada toplanan ham veriler araştırmacılar tarafından arşivlenmiştir.

\subsection{Verilerin Toplanması}

Veriler, araştırma ekibi tarafından yüz yüze görüşme yöntemiyle Sinop ilinde toplanmıştır. Görüşmeler katılımcıların isteği üzerine notlar tutularak gerçekleştirilmiş ve daha sonra düzenlenip düz yazı haline getirilmiştir. Toplam 8 kişi ile görüşülmüş ve her katılımcıdan ortalama A4 kâğıdı boyutunda iki sayfa veri elde edilmiştir. Görüşmelerde önce katılımcılar araştırmanın amacı ile ilgili bilgilendirilmiş, katılımcılara çalışmanın gönüllü katılıma dayandığı söylenmiş ve her bir katılımcıya bilgilendirilmiş gönüllü olur/onam formunun imzalatılmıştır.

\subsection{Verilerin Analizi}

Verilerin çözümlenmesinde "İçerik analizi” tekniğinden faydalanılmıştır. İçerik analizi bilimsel yöntemlerden faydalanılarak metin ya da diğer türdeki içeriklerin içeriğin özetlenmesi, sınıflanması ve mukayese edilmesi ve nicel olarak açıklanmasıdır (Chen, Monion ve Morrison, 2007). Bu yöntemde yüz yüze görüşme ile toplanan veriler, birbirinden habersiz üç değişik uzmanca deşifre edilmiştir, temalar ve kodlar belirlenmiştir.

\section{BULGULAR}

Araştırmanın amacı doğrultusunda toplanan veriler araştırma ekibi tarafindan çözümlenerek tablolar halinde sunulmuştur.

\section{Birinci araştırma sorusuna dair bulgular;}

Tablo 2'de, Emekli bireylerin serbest zamanlarını hangi aktivitelerle değerlendirdiklerine dair görüşlerinden elde edilen bulgular yer almaktadır. Buna göre katılımcı görüşleri; fiziksel aktivite, sosyal etkinlikler, açık hava etkinlikleri, temel eğlenceler, mental aktiviteler ve sosyal sorumluluk temalarından oluşmuş ve en yoğun ortak görüş belirtilen kodlar ise yüzme ve yürüyüş alt temalarındadır. 
Tablo 2. Emekli bireylerin serbest zamanlarını değerlendirdikleri aktivitelere dair görüşleri.

\begin{tabular}{|c|c|c|c|}
\hline Ana Tema & Alt Temalar & Görüşme Sonucu Ortaya Çıkan Kodlar & Katılımcı \\
\hline \multirow{12}{*}{$\begin{array}{l}\text { Serbest Zamanı } \\
\text { Değerlendirme }\end{array}$} & \multirow{4}{*}{ Fiziksel Aktivite } & Kültür fizik hareketleri & G1, G8 \\
\hline & & Yüzme & G1, G2, G3, G4, G5, G6, G7 \\
\hline & & Pilates & G7 \\
\hline & & Yürüyüş & $\begin{array}{c}\text { G1, G2, G3, G4, G5, G6, G7, } \\
\text { G8 }\end{array}$ \\
\hline & \multirow{3}{*}{$\begin{array}{c}\text { Sosyal } \\
\text { Etkinlikler }\end{array}$} & Arkadaşlarla vakit geçirme & G1, G4 \\
\hline & & Kurslara katılma & G5, G6 \\
\hline & & Konser & G4 \\
\hline & \multirow{2}{*}{$\begin{array}{l}\text { Açık hava } \\
\text { etkinlikleri }\end{array}$} & Balıkçılık & G2, G8 \\
\hline & & Kara avc1lı̆̆1 & G2 \\
\hline & \multirow{2}{*}{$\begin{array}{c}\text { Mental } \\
\text { aktiviteler }\end{array}$} & Kitap okuma & G2, G3, G7 \\
\hline & & Bulmaca çözme & G1, G2, G3 \\
\hline & $\begin{array}{c}\text { Sosyal } \\
\text { sorumluluk }\end{array}$ & Amatör spor kulübü yöneticiliği yapma & G4 \\
\hline
\end{tabular}

\section{Ikinci araştırma sorusuna dair bulgular;}

Tablo 3'de, emekli bireylerin serbest zamanlarında fiziksel aktivite/spor etkinliklerine katılıma dair görüşlerinden elde edilen bulgular yer almaktadır. Buna göre katılımcı görüşleri; sağlık, teşvik ve tatmin temalarından oluşmuş ve en yoğun ortak görüş belirtilen kodlar ise sağlıklı hissetme ve yaygınlaşması teşvik edilmeli olmuştur.

Tablo 3. Emekli bireylerin serbest zamanlarında fiziksel etkinliklere katılıma dair görüşleri

\begin{tabular}{|c|c|c|c|}
\hline Ana Tema & Alt Temalar & Görüşme Sonucu Ortaya Çıkan Kodlar & Katılımeı \\
\hline \multirow{7}{*}{$\begin{array}{l}\text { Serbest Zamanlarda fiziksel } \\
\text { aktivite yapmakla ilgili genel } \\
\text { düşünceler }\end{array}$} & \multirow{4}{*}{ Sağlik } & Sağlıklı hissetme & G1, G5, G6, G7, G8 \\
\hline & & Stresten arınma & $\mathrm{G} 2, \mathrm{G} 4$ \\
\hline & & Kilo verme & G2, G5 \\
\hline & & Yenilenmiş hissetme & G4 \\
\hline & \multirow{2}{*}{ Teşvik } & Yaygınlaşması teşvik edilmeli & G1, G3, G4, G6 \\
\hline & & Kötü alışkanlıklardan korunma & G4 \\
\hline & Tatmin & Kendini ișe yarar hissetme & G7 \\
\hline
\end{tabular}

\section{Üçüncü araştırma sorusuna dair bulgular;}

Tablo 4'te Emekli bireylerin Sinop ilindeki serbest zamanlarında yapılabilecek fiziksel aktivite/sportif etkinliklerin yeterliğine dair görüşlerinden elde edilen bulgular yer almaktadır. Buna göre katılımc1 görüşleri; uzman eksikliği, yerel yönetimler ve fiziki imkanlar temalarından oluşmuş ve en yoğun ortak görüş belirtilen kodlar ise yetersiz, rekreasyon alanlarının yetersizliği ve yeterli spor tesislerinin olmaması olmuştur. 
Tablo 4. Emekli bireylerin Sinop ilindeki serbest zamanlarında yapılabilecek fiziksel aktivite/sportif etkinliklerin yeterliğine dair görüşleri

\begin{tabular}{|c|c|c|c|}
\hline Ana Tema & Alt Temalar & Görüşme Sonucu Ortaya Çıkan Kodlar & Katılımeı \\
\hline \multirow{8}{*}{$\begin{array}{l}\text { Fiziksel aktivite yeterliliği } \\
\text { hakkındaki düşünceler }\end{array}$} & Yetersiz & Yeterli değil & $\begin{array}{l}\text { G1, G2, G3, G4, } \\
\text { G5, G6, G7, G8 }\end{array}$ \\
\hline & Uzman eksikliği & İstenilen aktiviteye uygun eğitmen olmamas1 & G7 \\
\hline & Yerel yönetimler & Belediyenin yetersizliği & G1, G3 \\
\hline & \multirow{5}{*}{ Fiziki imkanlar } & Bisiklet ve koşu yollarının olmaması & G2, G5 \\
\hline & & Su sporları anlamında eksiklikler & G2 \\
\hline & & Rekreasyon alanlarının yetersizliği & G3, G4, G8 \\
\hline & & Yeterli spor tesislerinin olmamas1 & G4, G5, G6 \\
\hline & & $\begin{array}{c}\text { Genç sporculara maddi anlamda destek } \\
\text { olunmamas } 1\end{array}$ & G2 \\
\hline
\end{tabular}

\section{Dördüncü araştırma sorusuna dair bulgular;}

Tablo 5'te, emekli bireylerin Sinop ilinde geçirdikleri serbest zamanlarında fiziksel aktivite/sportif etkinlik faaliyetleri yapmalarında engel olan durumlar hakkındaki görüşlerinden elde edilen bulgular yer almaktadır. Buna göre katılımcı görüşleri; tesis/malzeme, ulaşım, sosyal çevre, beslenme ve bürokrasi temalarından oluşmuş ve en yoğun ortak görüş belirtilen kodlar ise spor tesislerinin azlığı ve ulaşım sorunu olmuştur.

Tablo 5. Emekli bireylerin Sinop ilinde geçirdikleri serbest zamanlarında fiziksel aktivite/sportif etkinliklere katılımına engel olan durumlar hakkındaki görüşleri

\begin{tabular}{|c|c|c|c|}
\hline Ana Tema & Alt Temalar & Görüşme Sonucu Ortaya Çıkan Kodlar & Katılımeı \\
\hline \multirow{8}{*}{$\begin{array}{c}\text { Serbest zamanlarda fiziksel } \\
\text { aktiviteler yapilmasına } \\
\text { engel durumlar }\end{array}$} & \multirow{4}{*}{ Tesis/Malzeme } & Spor tesislerinin azlığ1 & G1, G3, G4, G5, G6, G7 \\
\hline & & Yürüyüş yollarının azlığı & G2, G7 \\
\hline & & Aletlerin yetersiz olması & $\mathrm{G} 2$ \\
\hline & & Spor aletlerinin her yaşa hitap etmiyor olması & G2 \\
\hline & Ulaşım & Ulaşım sorunu & G3, G6, G7, G8 \\
\hline & Sosyal çevre & Ailem ve arkadaşların baskısı & G1 \\
\hline & Beslenme & Sağlıksız beslenme & G1 \\
\hline & Bürokrasi & Resmi prosedürler konusunda engellerin olması & $\mathrm{G} 2$ \\
\hline
\end{tabular}

\section{Beşinci araştırma sorusuna dair bulgular;}

Tablo 6'da Emekli bireylerin Sinop ilinde serbest zaman etkinlikleri adına nelerin değiştirilmesi/yenilenmesi gerektiğine dair görüşlerinden elde edilen bulgular yer almaktadır. Buna göre katılımcı görüşleri; tesis, eğitim kursları, ulaşım, etkinlikler, sağlık ve sporu geliştirmek yaygınlaştırmak temalarından oluşmuş ve en yoğun ortak görüş belirtilen kodlar ise spor tesisi inşa etme ve sosyal ve sportif etkinlikler düzenleme olmuştur. 
Tablo 6. Emekli bireylerin Sinop ilinde serbest zaman etkinlikleri adına nelerin değiştirilmesi/yenilenmesi gerektiğine dair görüşleri

\begin{tabular}{cccc}
\hline \multirow{2}{*}{ Ana Tema } & Alt Temalar & Görüşme Sonucu Ortaya Çıkan Kodlar & Katılımcı \\
\hline & Tesis & Yeşil alan oranını artırma & G3 \\
\cline { 2 - 4 } & Eğitim kursları & $\begin{array}{c}\text { Kurslar açma ve kurumlar arası iş } \\
\text { birliği yapma }\end{array}$ & G1, G2, G4, G5, G6, G7, G8 \\
\cline { 2 - 4 } $\begin{array}{c}\text { Serbest zaman etkinlikleri } \\
\text { adına neler yapmak } \\
\text { istersiniz ya da } \\
\text { değiştirmek istersiniz? }\end{array}$ & Ulaşım & Ulaşım sorununu çözme & G7 \\
\cline { 2 - 4 } & Etkinlikler & Sosyal ve sportif etkinlikler düzenleme & G1, G2, G4, G5, G6 \\
\cline { 2 - 4 } & Sağlik & Artan obezitenin önüne geçecek & Ģalişmalar yapma \\
\cline { 2 - 4 } & $\begin{array}{c}\text { Sporu geliştirmek } \\
\text { yaygınlaştırmak }\end{array}$ & Sporun gelişimine katk1 & G1, G2, G8 \\
\hline
\end{tabular}

\section{TARTIŞMA VE SONUÇ}

$\mathrm{Bu}$ araştırma, Sinop ilinde yaşayan emekli bireylerin; serbest zamanlarını değerlendirme, fiziksel aktiviteye katılım, fiziksel aktivitelerin yeterliği ve katılıma engel durumlar ile şehirde serbest zamanla ilgili değiştirilmesi/yenilenmesi gereken konulara ilişkin görüşlerini tespit etmek amaciyla yapılmıştır.

Katılımcılar serbest zamanlarında genel olarak yürüyüş ve yüzme gibi fiziksel aktiviteler yapmakta olduklarını belirtmişlerdir. Bu sonucun temel nedenlerinden birinin şehrin fiziki imkanları ile ilgili olduğu söylenebilir. Konuyla ilgili literatürde yapılan çalışmalarda da kısmen benzerlikler görünmektedir. Örneğin Göktaş vd. (2016) yaşlı bireylerin serbest zamanlarını nasıl değerlendirdiği konusunda yaptıkları çalışmada katılımcıların ağırlıklı olarak ibadet, ziyaret, TV izleme ve yürüyüş gibi sonuçlar elde etmişlerdir. Nimrod (2007) de emekliler üzerine yaptığı çalışmada serbest zaman sınıflandırması için yaptı̆̆ı analizi sonucunda benzer sonuçlar elde etmiştir. Çalışma sonucunda ortaya çıkan bazı rekreatif etkinlikler; aile ve çocuklar ile vakit geçirmek, sinemaya gitmek, tiyatroya gitmek, konser izlemek, kitap-gazete okumak ve spor yapmaktır. Ekinci vd. (2014) de yaşlıların genel serbest zaman eğilimlerinin ağırlıklı olarak ev içi aktiviteler ve sportif aktivitelere katılmak olduğu sonucuna ulaşmıştır.

Katılımcıların serbest zamanlarda fiziksel/sportif aktivitelere katılımları ile ilgili görüşleri incelendiğinde genel olarak sağlık teması öne çıkmaktadır. Katılımcıların ilerleyen yaşları düşünüldüğünde sağlık açısından egzersiz ve sporun öneminin arttığı söylenebilir. Bireylerdeki değişen sağlık bilinci, mutluluğa olan gereksinimin gün geçtikçe artması rekreatif faaliyetlere katılımda motive edici unsurların başında gelmektedir (Yurcu, Kasalak \& Akınc1, 2017). Serbest zaman aktivitelerinin sağlıklı, dinlendirici, rahatlatıcı olduğu ve kişisel gelişime katkı sağladığı bilinmektedir (Nimrod, 2007). Ayrıca depresyon ve sıkıntı, benzeri işlerde ilgilenen bireylerde azalma yönelimlidir (Murphy, 2003). Zira serbest zaman etkinlikleri birey özgürlüğünün en az sınırlandığı çalışmalardır. Dolayısıyla serbest zaman etkinlikleri yalnızda bedensel iyi oluşa faydada vermez bunun yanında psikolojik sağlığa da katkıda bulunur (Şener, 2009). Dupius (1995) pasif (hobiler ve el sanatları), sosyal (arkadaş ziyaretleri) ve fiziksel (yüzme) aktivitelere katılımın yüksek olması ile psikoloji, iyi oluş ve düşük depresyon arasında anlamlı bir ilişki olduğunu ileri sürmektedir. Genelde yaşlı bireyler için yapılan rekreasyon çalışmaları yaşlıların; fiziksel, ruhsal ve sosyal açıdan iyi olmalarına katkı vererek yaşam standartlarını yükseltmeyi amaçlamaktadır (Aydın \& Tütüncü, 2017).

Katılımcılar, şehirdeki fiziksel aktivitelerin yeterliği ile ilgili olumsuz görüş bildirmişlerdir. Ayrıca bu alanda çalışacak uzman personel eksikliği olduğunu, yerel yönetimin fiziksel aktivite ile ilgili çalışmalarının yetersiz olduğunu ve şehirde bisiklet ve koşu yolları, spor salonları, rekreasyon alanları, spor tesisleri gibi fiziksel aktivite yapılabilecek imkanların yetersizliğine dair görüş bildirmişlerdir. Kalkınma 
Ajansları Genel Müdürlüğü tarafından yayınlanan "İllerin ve bölgelerin sosyo-ekonomik gelişmişlik sıralaması araştırması" raporuna göre Sinop ili 81 il arasında kendisine 5. Kademe iller arasında ve 52. sirada yer bulmuştur (SEGE, 2017: 56). Yine yerel yönetim birimi olarak Sinop Belediyesinin organizasyon yapısı incelendiğinde sporla ilgili bir birimin olmadığı gözlemlenmektedir (SB, 2020). Ayrıca Gençlik ve Spor İl Müdürlüğü uhdesindeki spor tesisleri incelendiğinde il merkezinde bir yüzme havuzu, iki çok amaçlı spor salonu, bir semt sahası, bir masa tenisi evi ve bir kapalı tenis kortu olduğu gözlemlenmektedir. Bu bağlamda katılımcı görüşleri de dikkate alındığında şehirdeki fiziksel aktivite ve spor alanındaki fiziki imkanların yetersiz olduğu söylenebilir.

Çalışmada elde edilen sonuçlardan birisi de rekreasyonel amaçlı fiziksel aktivitelerin önündeki engellere ilişkindir. Bu konuda katılımcılar en fazla spor tesislerinin azlığı konusunda görüş bildirmişlerdir. Şehirdeki kamu ve özel spor tesislerinin sayısal olarak az olması bu bulguyu desteklemektedir. Bununla birlikte çoğu katılımcı ulaşım sorunları konusunda da görüş bildirmişlerdir. Bu bağlamda yerel yönetimin şehir içi ulaşım hizmetlerini geliştirmesi ve trafik sorunlarına çözümler üretmesi, özellikle emekli bireylerin fiziksel aktivitelere katılımına yönelik tedbirler alması faydalı olabilir.

Katılımcılar ellerinde olsa şehirde serbest zaman etkinlikleri ile ilgili neleri değiştirmek isteyeceklerine dair görüşleri de rekreasyonel amaçlı fiziksel aktivitelerin önündeki engellerle ilgili kentte yaşanan bazı sorunlara işaret etmektedir. Katılımcılar ağırlıklı olarak tesis/malzeme ve ulaşım konularının engel teşkil ettiğini vurgulamıştır. Literatürde yapılan çalışmalar incelendiğinde benzer sonuçlar görmek mümkündür. Örneğin yapılan çalışmalarda serbest zaman etkinliklerine dahil olmadaki engellerin "sosyal ortam", "bilgi eksikliği”, "zaman ve tesis/hizmet/ulaşım" faktörlerinin olduğu vurgulanmıştır (Demirel ve Harmandar, 2009; Emir, Öncü \& Gürbüz, 2012). Ekinci (2014) te serbest zaman engellerinin gelir durumuna göre tesis/hizmet boyutunda anlamlı farklı1ık olduğu sonucuna ulaşmıştır.

Sonuç olarak Sinop ilinde yaşayan yaşlıların serbest zamanlarında fiziksel aktivite yapmaya karşı olumlu tutumları olduğu söylenebilir. Fakat şehirdeki spor tesisi ve ulaşım sorunu rekreatif aktivitelere katılım konusunda engel teşkil etmektedir. Öncelikle belediyeler ve spor hizmetleri ile alakalı kurumların spor tesisi ve ulaşım sorunlarını gidermesi serbest zaman etkinliklerine dahil olmayı yükseltecek önemli etkenler olacaktır.

Çatışma Beyanı: Yazarlar arasında herhangi bir çıkar çatışması yoktur.

Etik Kurul Onayı: Bu araştırma, Artvin Çoruh Üniversitesi Etik Kurulu'nun 25.03.2020 tarih ve 78646441-050.01.04 sayılı kararı ile etik açıdan uygun bulunmuştur.

\section{KAYNAKLAR}

Aksoy, R., Bakış, M. \& Ünveren, M. (2018). Spor Sosyolojisi. MEB Yayınları

Aydın, İ. \& Tütüncü, Ö. (2017). Yaşlılık ve Rekreasyon. Anatolia: Turizm Araştırmaları Dergisi, 28(2), 315-321.

Brizon, P. (1977). Emeğin ve Emekçilerin Tarihi. Onur Yayınları

Creswell, J. W. (2013). Nitel Araştırma Yöntemleri (3. Baskı). Çev. M. Bütün ve S. B. Demir. Siyasal Kitabevi.

Çelebi, M. \& Özbey: (2014). Rekreasyon Temelleri. N. Mirzeoğlu (ed), Spor Bilimlerine Giriş (269-300) İçinde, Spor Yayınevi ve Kitabevi.

Demirel, M. \& Harmandar, D. (2009). Üniversite öğrencilerinin rekreasyonel etkinliklere katılımlarında engel oluşturabilecek faktörlerin belirlenmesi. Uluslararası İnsan Bilimleri Dergisi, 6(1), 838-846.

Dupuis: L., \& Smale, B. J. (1995). An examination of relationship between psychological well-being and depression and leisure activity participation among older adults. Loisir et société/Society and Leisure, 18(1), 67-92.

Ekinci, N. E., Kalkavan, A., Üstün, Ü. D. \& Gündüz, B. (2014). Üniversite öğrencilerinin sportif ve sportif olmayan rekreatif etkinliklere katılmalarına engel olabilecek unsurların incelenmesi. Sportif Bakış: Spor ve Eğitim Bilimleri Dergisi, 1(1), 1-13. 
Emir, E., Öncü, E. \& Gürbüz, B. (2012). Rekreatif Etkinliklere Katılımın Önündeki Engellerin Belirlenmesi: Üniversite Öğrencileri Örneği Examination of Constraints to Leisure Activities in Turkish University Students. Journal of Human Sciences, 14(4), 3895-3904.

Gorz, A. (2001). Yaşadığımız Sefalet (Çev. Nilgün Tutal). Ayrıntı Yayınları.

Göktaş, A., Pekçetin, Tekindal, B., Kayıhan, H. \& Uyanık, M. (2016). Yaşlı Bireylerde Aktivite Tercihlerinin Bilişsel Beceriler ve Yaşam Memnuniyeti Üzerine Etkisi. Ergoterapi ve Rehabilitasyon Dergisi, 4(1), 1-14.

Hazar, A (2003). Rekreasyon ve Animasyon. Detay Yayıncılık.

Keser, A. (2009). Çalışma Psikolojisi. Ekin Basım Yayın Dağıtım.

Lee, K., Kim, K.R. \& Yi, E. (2014). The Effect of Push Factors in the Leisure Sports Participation of the Retired Elderly on Re-socialization Recovery Resilince. Journal of Exercise Rehabilitation, 10(2),92-99.

Mahiroğulları, A. (2005). Endüstri Devrimi Sonrasında Emeğin İstismarını Belgeleyen İki Eser Germinal ve Dokumacilar. Sosyoloji Konferansları, no. 32, 41-53.

Mansuroğlu: (2002). Akdeniz Üniversitesi Öğrencilerinin Serbest Zaman Özellikleri ve Diş Mekân Rekreasyon Eğilimlerinin Belirlenmesi. Akdeniz Üniversitesi Ziraat Fakültesi Dergisi, 15(2),53-62.

Miles, M. B. \& Huberman, A. M. (1994). Qualitative Data Analysis (Second Edition). Sage Publications.

Murphy, H. (2003). Exploring Leisure and Psychological Health and Wellbeing: Some Problematic Issues in the Case of Northern Ireland. Leisure Studies, 22, 37-50.

Nimrod, G. (2007). Retirees' leisure: Activities, benefits, and their contribution to life satisfaction. Leisure Studies, 26(1), 65-80.

Cohen, L., Monion, L. \& Morrison, K. (2007). Research methods in education. Routledge.

Önder, S. (2003). Selçuk Üniversitesi Öğrencilerinin Rekreasyonel Eğilim ve Taleplerinin belirlenmesi üzerinde Bir Araştırma. S. ̈̈. Ziraat Fakültesi Dergisi, 17(32), 31-38.

SB (2020, Nisan 06). Belediye Teşkilatı. Sinop Belediyesi https://www.sinop.bel.tr/sabit-sayfalar/belediyeteskilatimiz/ adresinden alınd1.

Sevim, Y. \& Şahin, J. (2007). Toplumun yeni yoksulları: Emekliler (Şanlıurfa İli Örneği). Sosyoloji Araştırmaları Dergisi, 1, 195-207.

Şener, A. (2009). Yaşlılık Yaşam Doyumu ve Boş Zaman Faaliyetleri. Sosyolojik Araştırmalar Dergisi, 1, 1-18.

SEGE (2020, Nisan 06). İllerin ve bölgelerin sosyo-ekonomik gelişmişlik sıralaması araştırması. https://www.bakkakutuphane.org/upload/dokuman dosya/1_sege-2017.pdf adresinden alınd1.

Şimşek, A. \& Büyükkıdık: (2015). Emekli öğretmenlerin yaşam doyumlarına ilişkin görüşlerinin incelenmesi. Mehmet Akif Ersoy Üniversitesi Ĕ̈itim Bilimleri Dergisi, 4(6), 19-40

Torkildsen, G. (1992). Leisure and Recreation Management. Third Edition. E \& FN Spon Press.

TÜİK, (2020, Mayıs 4). Toplumsal Yapı ve Cinsiyet İstatistikleri: Türkiye İstatistik Kurumu http:// www.tuik.gov.tr/PreHaberBultenleri.do adresinden alındı.

TİB, (2019, Eylül 9). 2013 Verileriyle Türkiye’de İllerin Gelişmişlik Düzeyi Araştırması. Tarihinde İş Bankası https://ekonomi.isbank.com.tr/ContentManagement/Documents/ar_07_2015.pdf adresinden alınd1.

TÜİK, (2019, Eylül 9). TÜİK Göç istatistikleri, TÜİK http://www.tuik.gov.tr/PreTablo.do?alt_id=1067 adresinden alınd.

İŞKUR, (2019, Eylül 9). Genel Mutluluk Düzeyi. Türkiye İş Kurumu https://biruni.tuik.gov.tr/medas/?kn=100\&locale=tr adresinden alınd1.

Uzun, M., \& Gözaydın, G. (2017). Tercih Edilen Rekreatif Alan ve Aktivite Çeşitlilikleri Çanakkale Örneği. Kilis 7 Aralı Üniversitesi Beden Ĕ̈itimi ve Spor Bilimleri Dergisi, 1(1) 1-14

Yıldırım, A. \& Simsek, H. (2016). Sosyal Bilimlerde Nitel Araştırma Yöntemleri (10. Baskı). Ankara: Seçkin Yayınc1lik.

Yurcu, G., Kasalak, M. A. \& Akıncı, Z. (2017, Ekim 13-15). Yaşlı Bireylerde Rekreatif Faaliyetlere Katılımı Etkileyen Faktörler. [Conference presentation] 7th International Conference of Strategic Research on Social Science and Education, 2017, Antalya, Turkey. 